\title{
Meteorological and Intelligence Evidence of Long-Distance Transit of Chemical Weapons Fallout from Bombing Early in the 1991 Persian Gulf War
}

\author{
James J. Tuite ${ }^{a}$ Robert W. Haley ${ }^{b}$ \\ a International Security and Risk Management Consultant (former National Security Advisor to the President pro \\ tempore, US Senate), Gretna, Va., and ${ }^{\text {b}}$ Division of Epidemiology, Department of Internal Medicine, University of Texas \\ Southwestern Medical Center, Dallas, Tex., USA
}

\section{Key Words}

Explosive agents $\cdot$ Chemical warfare agents $\cdot$ Sarin $\cdot$

Chemical alarms · Atmosphere - Meteorology • Persian Gulf syndrome $\cdot$ Epidemiology

\begin{abstract}
Background: Coalition bombings on the night of 18-19 January 1991, early in the Gulf War, targeted the Iraqi chemical weapons infrastructure. On 19 January 1991, nerve agent alarms sounded within Coalition positions hundreds of kilometers to the south, and the trace presence of sarin vapor was identified by multiple technologies. Considering only surface dispersion of plumes from explosions, officials concluded that the absence of casualties around bombed sites precluded long-distance transit of debris to US troop positions to explain the alarms and detections. Consequently, they were discounted as false positives, and low-level nerve agent exposure early in the air war was disregarded in epidemiologic investigations of chronic illnesses. Intelligence Data: Newly assembled evidence indicates that plumes from those nighttime bombings of Iraqi chemical facilities would have traversed the stable nocturnal boundary layer and penetrated the residual layer where they would be susceptible to rapid transit by supergeostrophic winds. This explanation is supported by plume height predictions, avail-
\end{abstract}

\section{KARGER}

E-Mail karger@karger.ch www.karger.com/ned

\section{(c) 2012 S. Karger AG, Basel} 0251-5350/13/0403-0160\$38.00/0

Karger

Open access

This is an Open Access article licensed under the terms of the Creative Commons Attribution- NonCommercial-NoDerivs 3.0 License (www.karger.com/OA-license), applicable to the online version of the article only. Distribution for non-commercial purposes only. able weather charts, weather satellite images showing transit of a hot air mass, effects of solar mixing of atmospheric layers, and observations of a stationary weather front and thermal inversion in the region. Conclusions: Current evidence supports long-distance transit. Epidemiologic studies of chronic postwar illness should be reassessed using veterans' reports of hearing nerve agent alarms as the measure of exposure.

Copyright $\odot 2012$ S. Karger AG, Basel

\section{Introduction}

The 1991 Persian Gulf War involved a 5-week air bombing campaign (17 January to 23 February 1991) followed by a 5-day ground assault (24-28 February 1991), together termed the 'conflict period'. During the first week of the air campaign, one significant military objective, according to published US government sources [1,2], was the destruction of the Iraqi chemical warfare agent infrastructure. US battlefield damage assessments confirmed that the intensive nighttime bombing campaign targeted facilities containing many tons of chemical warfare agents and precursor materials, stored in a variety of structures in bulk containers as well as in caches of chemical-filled artillery shells, located deep in Iraq (fig. 1) [3]. 
Fig. 1. Map of the central area of the Kuwaiti Theater of Operations in the 1991 Persian Gulf War, showing the two chemical weapons research, production and storage sites - the Muthanna State Establishment and Fallujah I, II and III bombed on the night of 18-19 January 1991; the locations of company-level US military units on 19 January 1991 when thousands of M8A1 chemical alarms sounded, and the approximate sites where low-level sarin and/or mustard agents were detected by chemical weapon experts with sophisticated detection equipment, listed in table 1 . Muthanna is $470 \mathrm{~km}$ from Rafha and $610 \mathrm{~km}$ from Hafir Al Batin. Symbols for military units located in the Persian Gulf represent US Navy vessels. Lakes Tharthar, Habbaniyah and Razazah are visible in several satellite images in figures 4-6. Deployed personnel numbered some 739,000 of the $2,066,000$ active duty US military personnel, which included personnel on regular active duty, activated Reserve and National Guard, and recalled retired personnel.

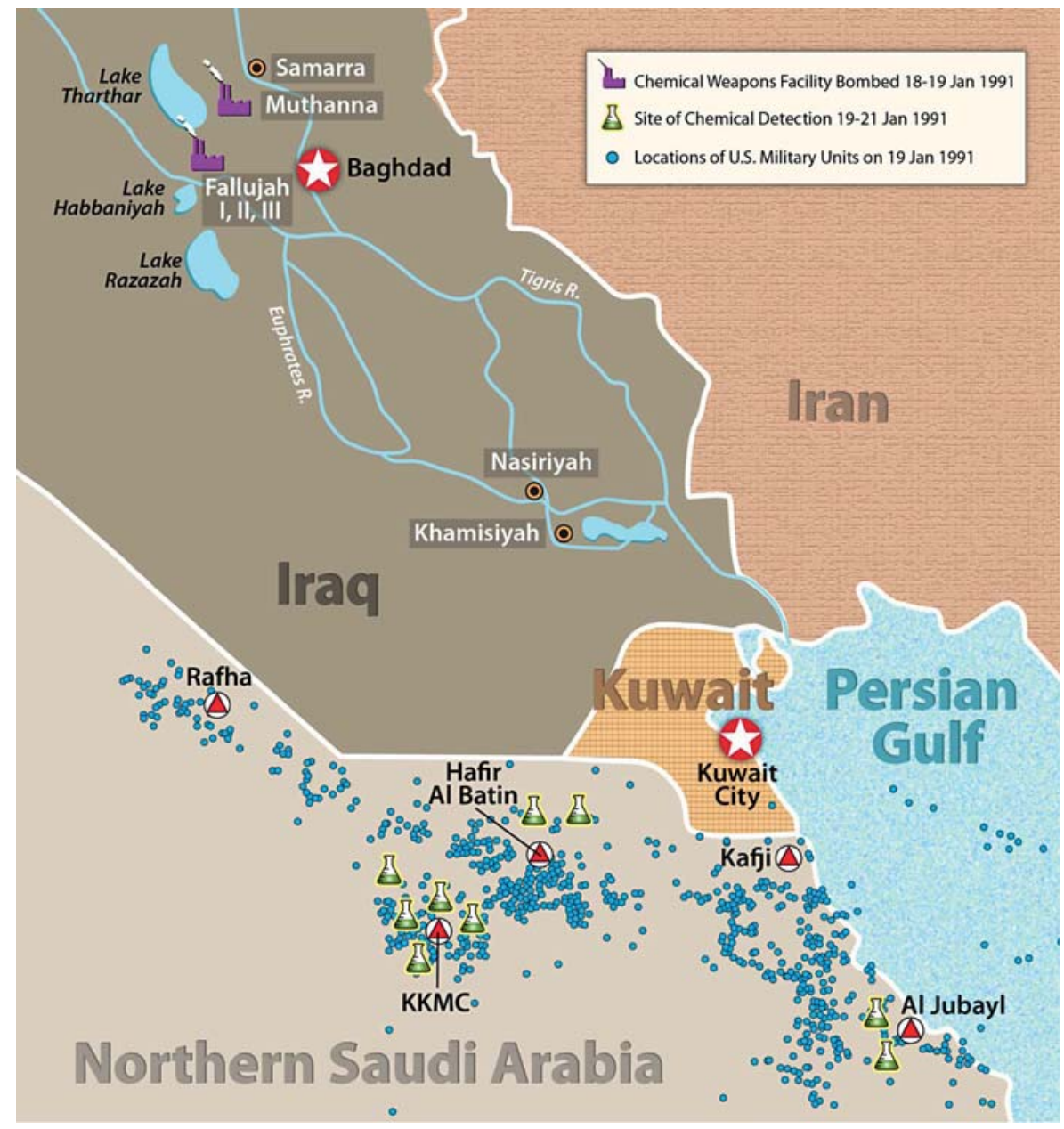

After the initial bombing, thousands of automated devices (predominantly the US M8A1 nerve agent alarm) widely deployed throughout US and Coalition troop concentrations to detect cholinesterase-inhibiting chemical nerve agents ('nerve agent alarms') began sounding [4], continuing over at least the following 2 days, in areas occupied by these forces located hundreds of kilometers southeast of the bombed sites (fig. 1). Expert teams from France and the Czech Republic, using sophisticated equipment, confirmed the presence of ambient sarin nerve agent and blister agent during this period (fig. 1; table 1), and US technical intelligence specialists officially assessed the Czech confirmations of sarin, which continued from 19 to 24 January, as 'valid' and 'credible' even though they could not determine the source $[5,6]$.

In the ensuing years, US government investigations of a potential link between these events relied on contemporary atmospheric transport and dispersion (ATD) model- ing methods [6-8], which estimated the extent of plumes expanding through the lower atmosphere near the surface directly from an emission source. When severe chemical casualties in populated areas near the bombed sites, predicted by ATD models of explosions at a chemical weapons storage facility, were not found, and surface winds were reported to be emanating from the wrong direction, US government analysts and the Task Force on Persian Gulf War Health Effects of the US Defense Science Board $[9,10]$ concluded that nerve agent emissions from the bombings could not have been appreciable and fallout from the bombings could not have reached US and Coalition troop positions. Thus, the close temporal association of the bombing with frequent widespread chemical nerve agent alarms confirmed by expert detections was left unexplained $[6,11,12]$.

Consequently, epidemiologic investigations of chronic illnesses among Gulf War veterans disregarded possible 
Table 1. Principal reported detections of chemical warfare $(\mathrm{CW})$ agents by chemical weapons experts using specialized identification equipment in Saudi Arabia, 19-21 January 1991

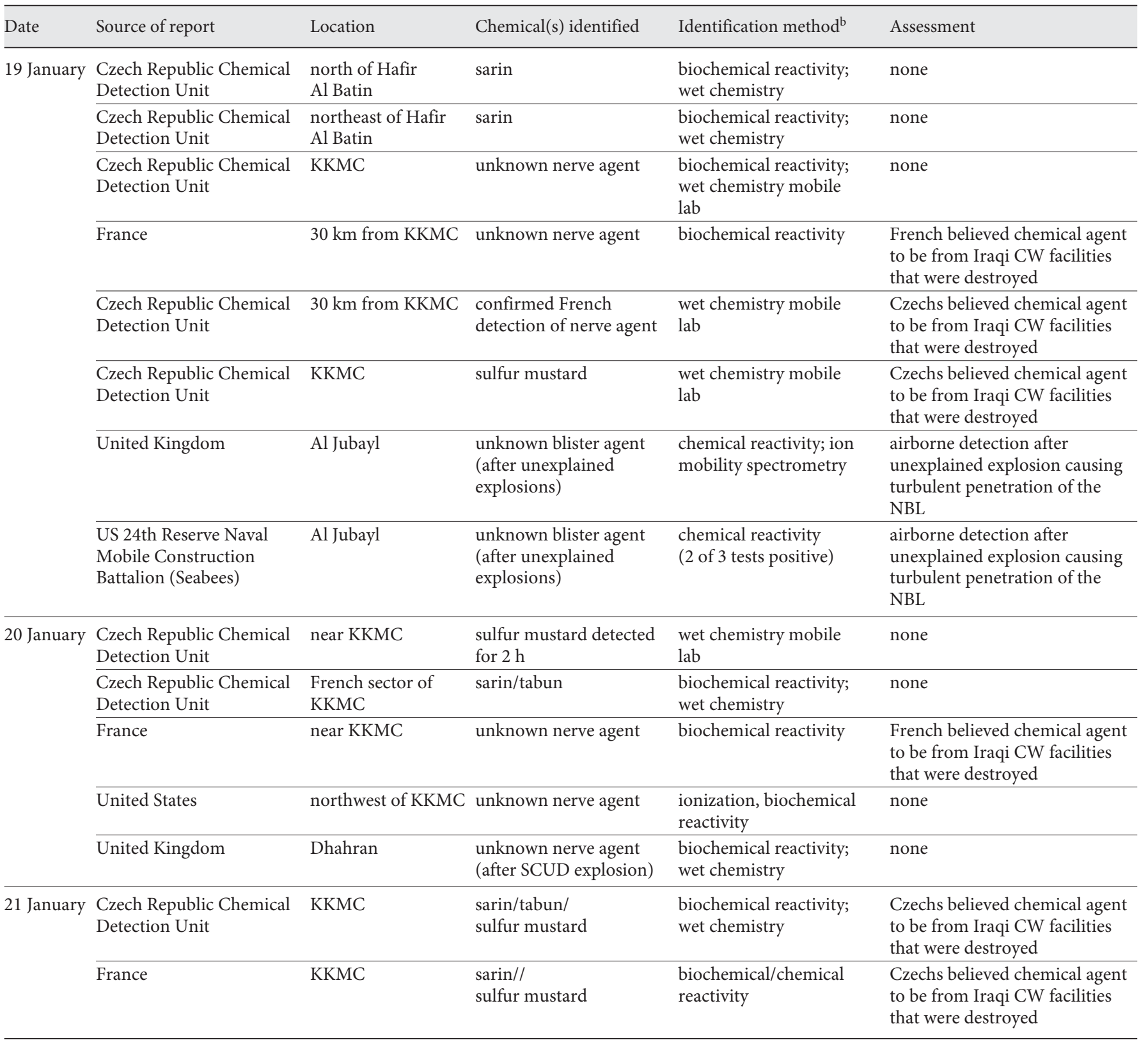

KKMC = King Khalid Military City, a large Coalition military concentration in north-central Saudi Arabia near Hafir al Batin.

a Based on concurrent media accounts $[36,37]$ and later published US government reports [10, 38, 39].

${ }^{\mathrm{b}}$ Biochemical reactivity: enzymatic technique using surrogate compounds for human acetyl cholinesterase, such as dry eel cholinesterase applied onto a fiber or other base. Wet chemistry: identification using chemistry based upon the use of reagents or compounds and laboratory equipment. Ionization: identification by exposing suspect gas vapors to ultraviolet energy powerful enough to ionize agent molecules. An ion detector then quantified the ionized molecules. Thus, these detectors determine the identity and concentration of the agent. Ion mobility spectrometry: air molecules are ionized using radioactive beta emitters. The ionized particles are passed through a weak electrical field toward an ion detector. Contaminants are identified based on the time it takes to traverse the distance to the detector. The time is proportional to the mass of the molecule. Flame spectrophotometry: a method used to determine the intensity of radiations of various wavelengths in a spectrum emitted by a chemical inserted into a flame. 
exposures from releases during the early phase of the air campaign, which were temporally associated with the widespread nerve agent alarms and detections. The studies focused instead on possible nerve agent exposure from fallout released from demolitions of the Iraqi ammunition dump at Khamisiyah, Iraq (fig. 1), 10-12 days after the end of the conflict period at a time when chemical nerve agent detection devices were no longer activated [8]. At the time of the demolitions, the Khamisiyah ammunition dump was not known to contain sarin-filled munitions. Onsite inspections by the United Nations Special Commission on Iraq in late October to early November 1991 determined that some nerve-agent-containing munitions had been destroyed there, but the numbers of munitions destroyed or damaged and the amount of nerve agent released by the postconflict demolition could not be determined [7, 13]. Nevertheless, results of computer simulations of the possible plume predicted by assumptions of the estimated amount of nerve agent released, blast strength and height, wind directions and speeds, weather conditions, etc., were released in 1997 [14] and in revised form in 2000 [13, 15]. To estimate the number of personnel who might have been exposed if the demolition had released sarin in fallout, Geographical Information System analysis identified all personnel located in the plume on each day according to the location coordinates of their military units, which had been reconstructed for approximately three quarters of deployed units. Epidemiologic studies using measures of sarin exposure from the plume models were about equally divided on whether chronic illness was associated with postwar demolition exposure. As a result, despite the temporal association between bombing chemical warfare agent storage sites and widespread nerve agent alarm activity early in the air campaign as well as the evidence of clinically similar chronic illnesses in survivors of the 1995 Aum Shinrikyo sarin attack in the Tokyo subway $[16,17]$, a role of exposure to low-level nerve agents in causing Gulf War illness has been largely discounted by US government officials and scientific reviewer panels $[18,19]$.

The purpose of this article is to reexamine the possible role of low-level nerve agent exposure from fallout released by the bombing of Iraqi chemical weapons production and storage facilities early in the air campaign. This involves bringing together the currently unclassified evidence explaining how nerve-agent-containing fallout from bombings, some of which were hundreds of kilometers away, could have reached US and Coalition troop positions without causing casualties in between. Specifically, the evidence addresses how high kinetic and thermal energy explosions at Iraqi chemical research, production and storage sites would have penetrated the stable nocturnal surface layer of the atmosphere, reaching higher level winds that carried a fallout cloud over US and Coalition positions in northern Saudi Arabia during the course of the night, then triggering the many reported alarms and detections. The scenario is supported by weather charts showing compatible wind directions aloft and meteorological satellite imagery data confirming hot air plumes developing over the areas of the bombed sites and transiting overnight toward Coalition troop positions where the detections occurred. Daytime solar mixing and an observed thermal inversion in the region on 19 January 1991 then brought upper air flows to the ground, resulting in frequent nerve agent detections, and a nearstationary weather front stalled in this area for several days as solar- and turbulence-related atmospheric mixing continued exposing ground troops to the fallout at concentrations sufficient to result in irreversible or other serious, long-lasting adverse health effects. A companion paper [20] reports an epidemiologic study in a population-representative sample of Gulf War veterans designed specifically to test whether hearing nerve agent alarms early in the air campaign was associated with chronic neurocognitive symptoms of Gulf War illness.

\section{Methods}

Technical and intelligence information was assembled from unclassified and declassified US government sources and from reports of the United Nations and several of the nations that participated either in the 1991 Gulf War conflict or in the postwar investigations of the chemical warfare agent program. The information was analyzed to reconstruct the nature and scope of the Iraqi chemical warfare agent research, production and storage program and the locations, magnitude, damage, and destruction of its infrastructure and inventories by US and Coalition bombing during the 1991 air campaign. Earlier versions of this analysis were reported to Congress $[4,7]$.

The technical and intelligence information was further explored to document the detections and confirmations of ambient chemical agents reported by US, French, British and Czech experts deployed for defensive purposes during the conflict period and assessments of the underlying conditions that resulted in the detections. This included documentation of the technical performance specifications and parameters of available chemical warfare agent monitoring, detection, and testing equipment available to the members of the US, French, British and Czech forces during the conflict.

Meteorological charts and recorded observations were obtained from the National Oceanographic and Atmospheric Administration (NOAA) and the US Air Force and were examined to determine wind directions aloft and any anomalous occurrences, such as inversion activity or stagnant meteorological patterns, during the period under examination. 
Meteorological satellite imagery data was obtained from NOAA polar-orbiting satellites (NOAA-10, NOAA-11) and the European Organization for the Exploitation of Meteorological Satellites (EUMETSAT) geostationary satellite (METEOSAT-4) to determine observable significant or anomalous meteorological activity in the region. Remote sensing analysis and spatial modeling software (ERDAS IMAGINE versions 8.2 and 2011) was used to acquire, geo-locate and interpret satellite imagery data.

\section{Review of Intelligence Data Relevant to Long-Distance Transit}

\section{Bombing of Iraqi Chemical Facilities}

Postconflict inspections provided evidence that vast quantities of chemical warfare agent materials were destroyed by bombings during the conflict period. After the war, Iraq declared that more than 4,800 chemical munitions (including 4,660 122-mm rockets and 12 aerial bombs containing sarin), 823 tons of key precursors and the majority of its chemical weapons production facilities were destroyed during the 1991 Persian Gulf War [21]. Principal among the Iraqi chemical weapons research, production and storage sites bombed the nights of 18-21 January 1991 were the Muthanna State Establishment (also referred to as Samarra) - the headquarters of the Iraqi chemical weapons research, production and storage program located northwest of Baghdad - and the string of chemical weapons factories, Fallujah I, II, and III (also referred to as Habbaniyah I, II, III), located west of Baghdad [22]. At Muthanna, munitions containing an estimated 16.8 metric tons of sarin or cyclosarin were damaged [23].

\section{Explosive Plume Geometry and Height}

With the detonation of a bomb and the potential ignition of secondary fires, the air immediately above the bombed area becomes extremely hot and is thrust upward rapidly. Intense high explosive plumes form, in part, as the result of the rapid formation of hot low-density gasses near the ground where the air is denser. As illustrated in figure 2a, b, Rayleigh-Taylor instability (where the mass of gas rises rapidly, resulting in vertical vortices, drawing up a column of vapor and debris in the center to form a 'stem') occurs with conventional bomb explosions and is not limited to nuclear bomb blasts.

The height to which a plume from a high explosive explosion will rise is estimated by a power law (fig. 2c). The power law function for plume heights at $2 \mathrm{~min}$ after detonation is:

$$
\mathrm{h}=76\left(\mathrm{w}^{1 / 4}\right)
$$

where $\mathrm{h}=$ height of plume in meters and $\mathrm{w}=$ weight of explosives in pounds [24].

Accordingly, a US MK- 84 bomb containing $942.6 \mathrm{lb}$ of high explosives would generate a plume 421 meters high; therefore, the explosive detonation of the typical 1,000or 2,000-lb bomb used in the Gulf War at night would rapidly produce a plume sufficiently high to penetrate the nocturnal boundary layer (NBL) and deposit the bulk of the material release into the residual layer (RL) (fig. 2a, d) [24-26]. The heat and pressures added by secondary explosions and fires, if present, would further extend plume heights.

Penetration of suddenly introduced explosion-related hot gases through the NBL into the RL may also be accentuated by surrounding cold temperatures at the surface (fig. 2a). This phenomenon would result from the increased divergence of the relative heat, and therefore densities, of the associated air masses. Between 18 and 20 January 1991, the surface nighttime low temperatures at the suspected release sites, as evidenced by the reporting weather stations in the region, were between $-4^{\circ} \mathrm{C}$ and $3^{\circ} \mathrm{C}$ [27].

\section{Preservation of Sarin in an Explosion}

Sarin is an organophosphate chemical nerve agent, which evaporates at about the same rate as water and has a boiling point of $158^{\circ} \mathrm{C}\left(316^{\circ} \mathrm{F}\right)$. It does not readily burn and does not burn at all in its pure form [28]. The destruction of weapons facilities in the Gulf War was accomplished primarily with high-explosive missiles and bombs, which produce instantaneous and extreme blast forces, shock and pressure waves, and heat. Rather than destroying it, high-explosive bombs, which instantaneously propel their plumes upward with extreme shock and pressure waves, would disseminate sarin into the atmosphere as vapor or even liquid mixed with other debris.

\section{Properties of the Nocturnal Boundary Layer}

Well-established atmospheric principles and plume analyses support the potential for the vertical distribution and long-range dispersal of chemical weapons fallout from the bombed facilities. Patterns of dispersion and transit from atmospheric releases differ fundamentally depending on whether they occur during the day or at night. As explained by Stull [26], during the day the 1- to $2-\mathrm{km}$ atmospheric boundary layer is composed of a thin surface layer, extending to $10-40 \mathrm{~m}$ above the surface, and the higher mixed layer, in which buoyancy and vertical wind shear cause intense turbulent mixing (fig. 2d). ATD modeling typically accounts well for surface-layer fluxes, winds, and temperatures of the daytime atmosphere. 


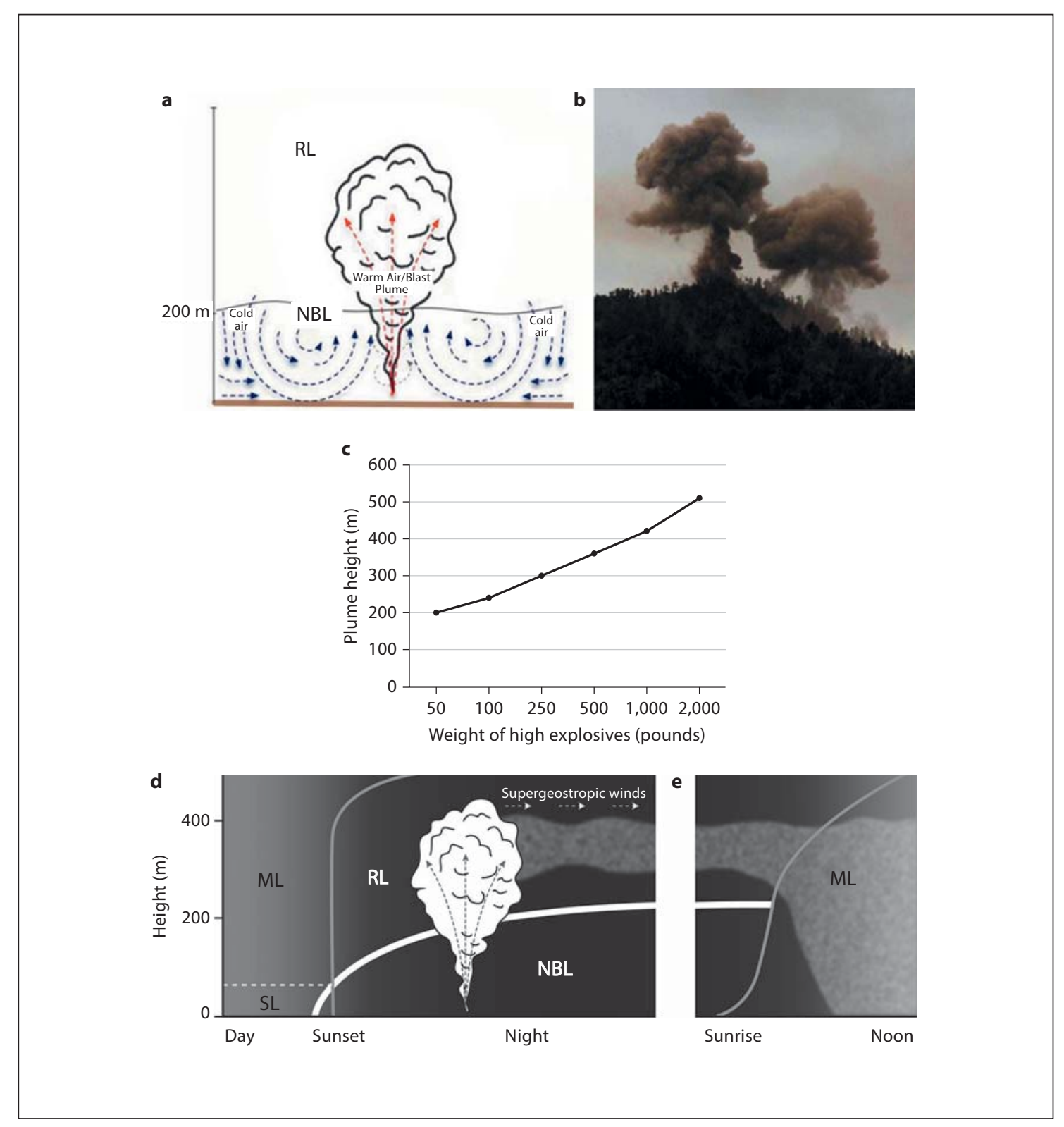

Fig. 2. Predicting the height of the plume from a bomb explosion and its penetration of the nocturnal boundary layer into the residual layer, and overnight long-distance transit. a Near-instantaneous Rayleigh-Taylor instability created by a bomb explosion causing the rise of gases, vapor and debris beyond the top of the NBL into the RL. The mass of gas rises rapidly, resulting in vertical vortices that draw up a column of vapor and debris in the center to form a 'stem'. b Photograph illustrating a typical plume created by the explosion of a high-explosive bomb (reproduced from Reuters News Services, December 14, 2001, reprinted with permission). c Power law function for predicting explosion plume height (in meters) from the weight of explosives (in pounds), derived from data on 23 test detonations ranging from 140 to 2,242 lb of high explosives at the US Department of Energy's Nevada Test Site [24]. Most of the shots were detonated during near-neu- tral conditions, where the clouds continued to rise after $2 \mathrm{~min}$; data for $5 \mathrm{~min}$ after detonation on some shots show tops rising to double the 2-min values. According to the study, the 2-min values may better represent the final cloud-top heights during stable conditions [24]. d The plume from the explosion of a 1,000$\mathrm{lb}$ bomb explosion would rise to a top height of approximately $421 \mathrm{~m}$, carrying most of the debris through the NBL, where the air is usually relatively calm, above $200 \mathrm{~m}$ into the RL where supergeostrophic nocturnal jets may carry the debris laterally at speeds of $10-30 \mathrm{~m} / \mathrm{s}[24,26]$. e After daybreak, convective heating by the sun causes the mixed layer to reform, allowing the fallout to reach the surface, setting off nerve agent alarms and exposing military personnel [26]. Adapted with permission from Stull [26]. $\mathrm{ML}=$ Mixed layer, $\mathrm{SL}=$ surface layer. 
At night, however, when radiative cooling replaces solar heating, the mixed layer loses its turbulence and partitions into the stable NBL up to approximately $200 \mathrm{~m}$ and a higher RL [26], as illustrated in figure 2d. Wind speeds just above ground level in the NBL are often light or calm; however, in the higher RL winds may reach supergeostrophic speeds of $10-30 \mathrm{~m} / \mathrm{s}(30-108 \mathrm{~km} / \mathrm{h})$ in low-level nocturnal jets [26]. In contrast to daytime conditions, the NBL is typically nonbuoyant, resists vertical motion, and supports only weak lateral motion with little mixing. According to the Joint Action Group for Atmospheric Transport and Diffusion Modeling of the Office of the Federal (US) Meteorological Coordinator [29], these characteristics are not handled well by conventional ATD modeling. The bombing of Iraqi chemical weapons research, production and storage facilities early in the air campaign was conducted almost entirely at night [1].

\section{Long-Distance Transit by Advection}

Gases released in an explosion eventually reach an altitude where they are no longer less dense than the surrounding air and disperse; however, at night, stability and reduction in turbulence reduces downward mixing back to the surface [26]. During these periods, gases emitted through the NBL into the RL may be conveyed by lowlevel jets (nocturnal jets), horizontal movements of air masses and associated vapor and debris advected at supergeostrophic speeds hundreds of kilometers from their source [26].

Low-level jets are not rare phenomena, having been documented in Europe, Africa, North and South Ameri$\mathrm{ca}$, and Australia [26], and even in complex urban terrain [30]. While low-level jets have not been studied in the Tigris-Euphrates valley, a northerly (from the north) one has been identified in the Lut Valley in neighboring Iran, which has terrain similar to that of central Iraq [31].

\section{Solar Mixing of Atmospheric Layers}

With the rise of the morning sun, solar heating currents create turbulence in the boundary layer, mixing the stable NBL and RL and reforming the mixed layer that persists throughout the day [26]. This re-formation of the mixed layer brings the contents of the NBL and RL back into contact with the surface (fig. 2e).

\section{Retention of Low-Level Chemical Warfare Agent in Atmospheric Layers}

When night returns, as radiative cooling again replaces solar heating and the mixed layer loses its turbulence and partitions into the stable NBL up to approximately
$200 \mathrm{~m}$ and a higher residual layer RL [26], each layer will now contain residual levels of debris that had remained in the mixed layer, thus perpetuating conditions suitable for extended exposure to residual chemical warfare agent fallout.

\section{Atmospheric Mixing of Chemical Weapons Precursors}

Chemical warfare agent precursors or components (many of which are health hazards) from the bombing of multiple sites had ample time to mix during advection periods. While it is impossible to determine how these compounds may have interacted during transport, it is possible that, in addition to fallout from the chemical warfare agent itself, other hazardous precursor materials may have been aloft or been created by combustion or mixing of component chemicals in the advection streams. The probability of such mixing is increased by the temporal and geographic proximity of the diverse sites bombed (fig. 1).

\section{Wind Directions Inferred from Weather Charts}

Any explanation of the link between the bombing in Iraq on the night of 18-19 January 1991 and chemical detections in US and Coalition positions the next day requires analysis of wind directions between the two distant sites. The US government analysis that resulted in the decision to disregard the link between the bombings and the detections relied on wind measurements made at a US Air Force weather station located on the Persian Gulf coast where surface winds were recorded as southerly and easterly [32], opposite the direction that would explain the linkage. Wind directions were not recorded further inland to the west in Saudi Arabia where the chemical detections were made or in Iraq where the bombings occurred.

Inland wind directions, however, can be determined from the locations of low-pressure areas (resulting in cyclonic or counterclockwise circulation) and high-pressure areas (resulting in anticyclonic or clockwise circulation) on weather maps of the region available from NOAA or by using Buys Ballot's rule: essentially, a person standing with their left side toward lower pressure will feel the wind hitting their back (fig. 3b, red annotations). NOAA pressure charts covering Iraq and Saudi Arabia show adjacent low- and high-pressure areas predicting northerly winds between Muthanna and US positions (e.g. Hafir al Batin) both at the surface $(1,000$ mbar) and at higher altitude ( 850 mbar) throughout the night of 18-19 January and persisting at least through 20 January (fig. 3) [33]. 


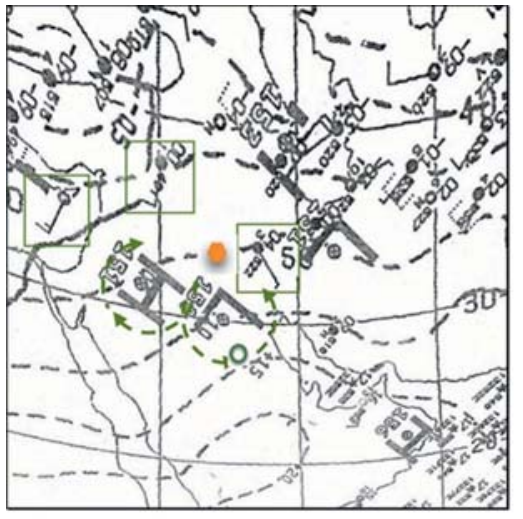

a 850 mbar Height/Temperature Char

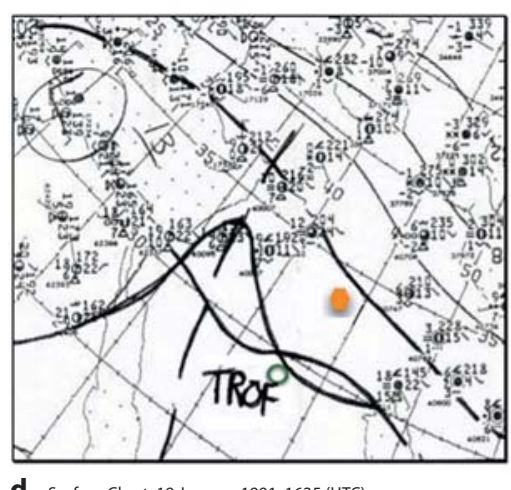

d Surface Chart: 19 January 1991, 1625 (UTC)

Local time $=\mathrm{UTC}+3 \mathrm{~h}$

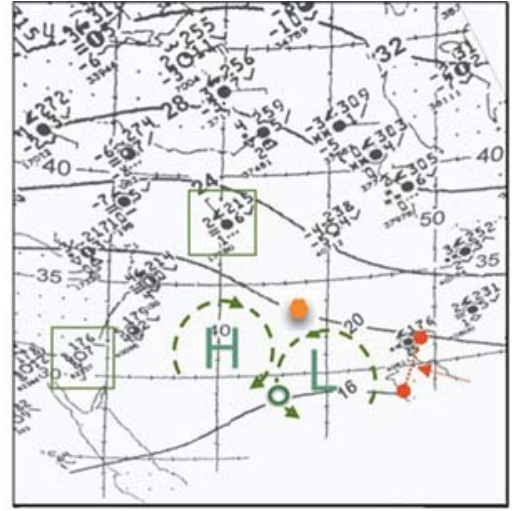

b Surface Chart: 19 January 1991, 0425 (UTC)

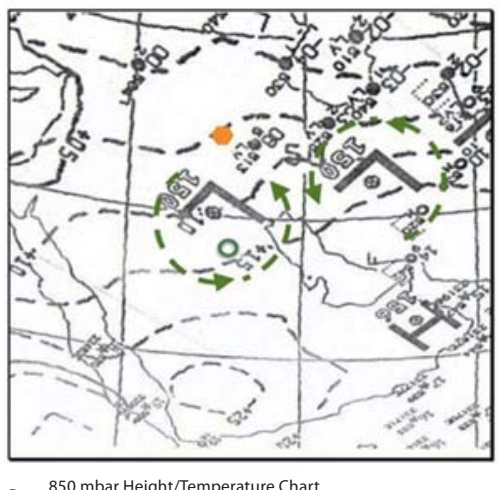

e 850 mbar Height/Temperature Chart

Muthanna State Establishement, IZ

O Hafir al Batin, SA

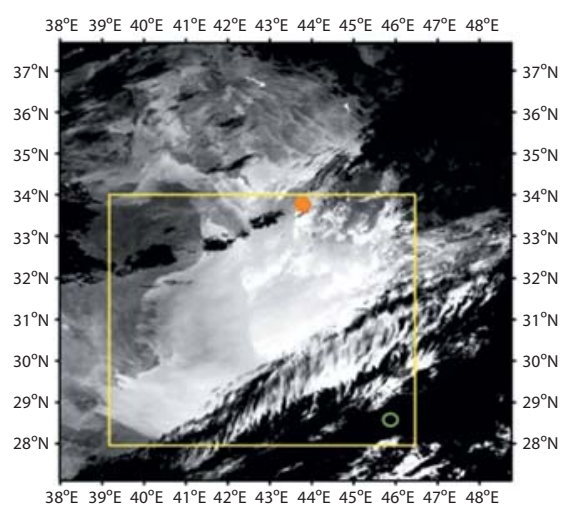

NOAA-10 AVHRR-1B, Ch 4, IR 19 January 1991, 0405-0552 (UTC)

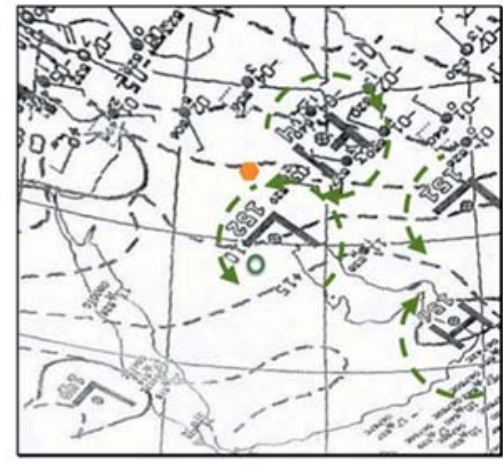

850 mbar Height/Temperature Chart
20 January 1991, 0000 (UTC)

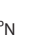

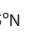

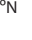 . (n)

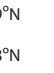


The wind directions inferred from the information in the charts are precisely those required to explain the link between bombings and detections. These weather charts also correctly predict the easterly and southerly wind directions recorded by the US Air Force weather station further east on the Persian Gulf coast as well as the surface wind directions recorded at the other nearest weather stations in the region, namely, southerly winds recorded in Egypt (station 62337 near El Arish, $31^{\circ} 05^{\prime} \mathrm{N}$ $033^{\circ} 49^{\prime} \mathrm{E}$ ) and northwesterly winds recorded in Turkey (station 17280 near Diyarbakir, $37^{\circ} 53^{\prime} \mathrm{N} 040^{\circ} 11^{\prime} \mathrm{E}$ ) (fig. 3).

\section{Visual Evidence of Transit from Weather Satellite Imagery}

During the Gulf War NOAA-10 and NOAA-11 polar earth-orbiting meteorological satellite images were routinely recorded unrelated to the military actions. Images recorded over the Kuwaiti Theater of Operations on 1819 January 1991 reveal a large visible and thermal (infrared) area of activity, absent in the image recorded between 18.00 and $19.00 \mathrm{~h}$ local time (Universal Time Coordinated, UTC $+3 \mathrm{~h}$ ) on 18 January (fig. $4 \mathrm{a}$ ) but present in the image recorded just after $03.00 \mathrm{~h}$ local time (UTC +3 h) on 19 January. Figure 4 shows this thermal area arising from the areas above the Muthanna and Fallujah I, II, III chemical weapons research, production and storage facilities (fig. 4b) and extending to a weather front located just north of US troop positions in the vicinity of Hafir Al Batin in the image recorded from 07.05 to $08.22 \mathrm{~h}$ local time (UTC $+3 \mathrm{~h}$, fig. $4 \mathrm{c}$ ). Infrared images collected every $30 \mathrm{~min}$ by the METEOSAT- 4 geostationary satellite also tracked and confirmed the origin and development of this formation (fig. $4 \mathrm{~d}-\mathrm{h}$ ) (for hot air mass transit, see online suppl. video 1, www. karger.com/doi/10.1159/000345123).

The nature of this formation and its extension to US and Coalition troop positions in the vicinity of Hafir $\mathrm{Al}$ Batin by the afternoon of 19 January are best discerned in the NOAA-11 composite multispectral satellite image recorded between 14.25 and $14.33 \mathrm{~h}$ local time (UTC + 3 h; Advanced Very High Resolutions Radiometer AVHRR - visual channel 1 and infrared channels 2 and 4) [34] (fig. 5).

\section{Evidence of a Thermal Inversion over US and Coalition Troop Concentrations}

Normally the atmosphere is warmest at the surface of the earth, which is warmed by solar radiation, and convection heat transfer from the surface upward encour- ages the upward diffusion of air, thus dissipating air pollutants near the surface. When a warm air mass moves over the top of a cool air mass, it may form a 'cap', preventing upward diffusion and trapping pollutants near the ground. Debris carried by advection in the RL might also be mixed with the surface layers when encountering a thermal inversion [26].

Both the satellite images (fig. 4) and the $850 \mathrm{mbar}$ weather charts (fig. $3 \mathrm{~d}$ with the NOAA annotations) indicate that a thermal inversion occurred in the vicinity of US and Coalition positions in northern Saudi Arabia on 19 January 1991 (for images of the weather pattern activity, see online suppl. video 1). This thermal inversion was observed as the mass of warm air that had arisen earlier over the sites of the bombings at the Muthanna and Fallujah I, II and III facilities and other locations converged with the frontal formation over US and Coalition troop positions in northern Saudi Arabia, resulting in atmospheric instability and fallout (fig. 4-6).

\section{Evidence of a Stationary Front Blocking the Fallout-Containing Air Mass}

Stalled weather fronts may hold a large mass of air in place for days at a time. NOAA-11 meteorological satellite imagery confirms stationary fronts stalled in the region from 18 to 24 January 1991 (fig. 6), coinciding with the period of the Czech detections (table 1) [6]. This appears to have prolonged the presence of the fallout-containing air mass over US and Coalition troop positions.

\section{Turbulence-Related Chemical Warfare Agent \\ Detection Activity}

Under normal conditions debris emitted into the top of the NBL or into the RL rarely disperses to the ground during the night because of limited turbulence. On the battlefield (and possibly in other special circumstances), however, unusual turbulence patterns can develop from causes that are otherwise unaddressed by meteorological models. Several documented nocturnal turbulence-related events associated with chemical warfare agent detections occurred in areas occupied by Coalition forces between 19 and 21 January 1991 that might have contributed to spatially limited mixing of the upper and surface atmospheric layers, thereby causing the detections. These turbulence-related events included low-level flyovers by supersonic aircraft, explosions of incoming artillery and ballistic (SCUD) missiles, and otherwise unexplained explosions [4]. Explosions or sonic booms produce shock waves and turbulence that may mix atmospheric layers [35]. 


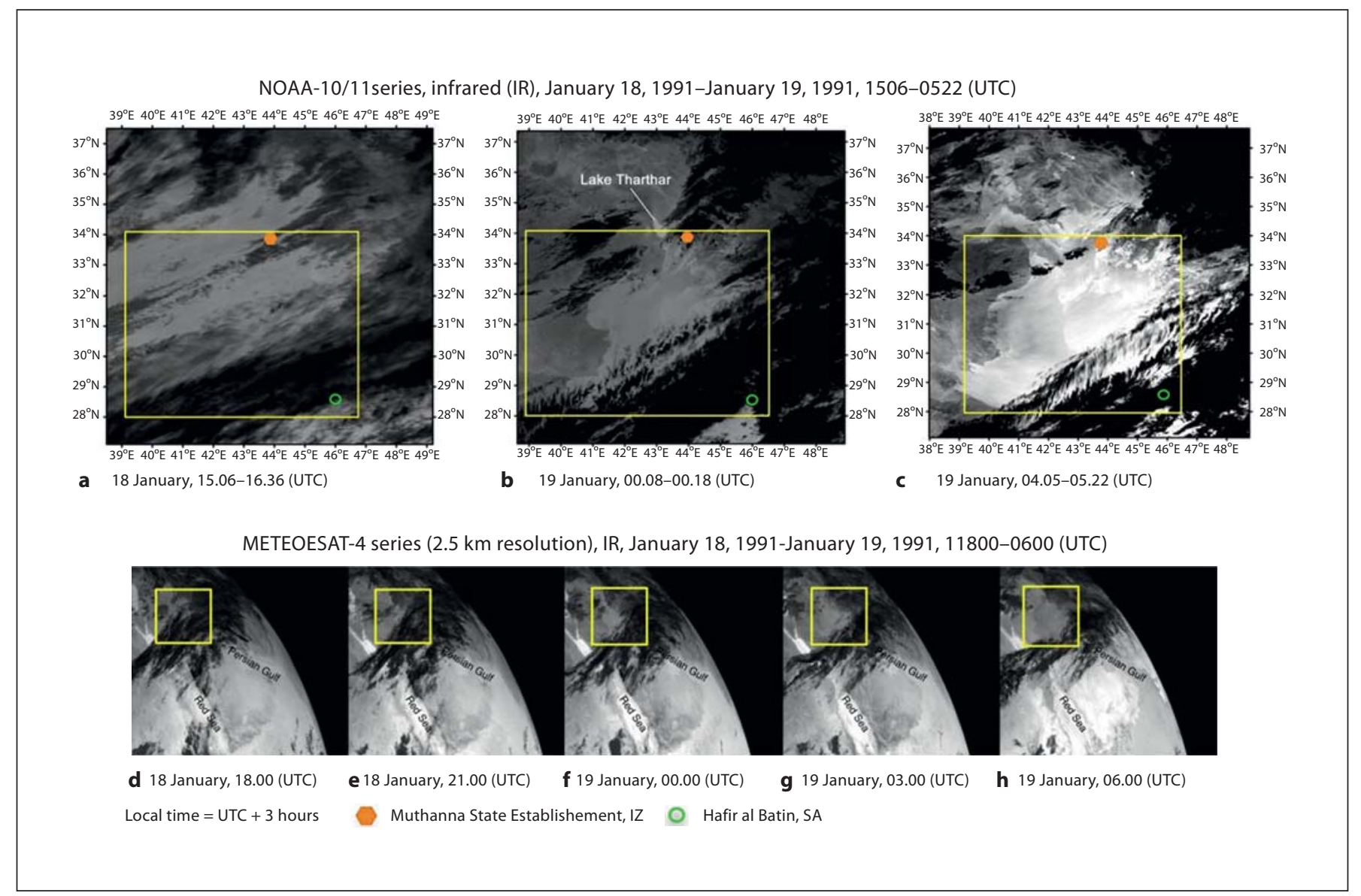

Fig. 4. Serial infrared weather satellite images over the Kuwaiti Theater of Operations from approximately $19.00 \mathrm{~h}$ local Asia/ Baghdad Standard Time (UTC $+3 \mathrm{~h}$ ) on Friday, 18 January, through $09.00 \mathrm{~h}$ local time (UTC $+3 \mathrm{~h}$ ) on Saturday, 19 January, the third night of the 5 -week air campaign. The yellow rectangle demarcates an area of approximately $600 \times 600 \mathrm{~km}$, extending from approximately $28^{\circ} \mathrm{N}$ to $34^{\circ} \mathrm{N}$ latitude and from $39^{\circ} \mathrm{E}$ to $46^{\circ} \mathrm{E}$ longitude, which includes Iraqi chemical weapons research, production and storage facilities at Muthanna and Fallujah I, II, III at the top (orange solid dot), which were bombed over this night, and Hafir Al Batin (green open dot), the area in which Coalition chemical warfare agent detections began on this day (table 1). Very dark shades indicate the coldest temperature in natural cloud formations; very light shades indicate bodies of water such as Lake Tharthar and the Red Sea, which retain heat overnight; and gray areas indicate the clouds of warm gases, vapor and debris

\section{Chemical Alarms and Detections of Nerve and \\ Blistering Agents}

According to concurrent media accounts $[36,37]$ and later published US government reports [38, 39], nerve agent alarms (mostly US M8A1 detector) sounded frequently during the early conflict period. Documented rising from the facilities bombed by Coalition missiles and aircraft. a-c NOAA-10 and NOAA-11 infrared satellite images showing the development of thermal activity originating after $19.36 \mathrm{~h}$ local time (UTC $+3 \mathrm{~h}$ ) from the area of the Coalition bombings and extending southward through the night to the area of Coalition chemical warfare agent detection activity [56]. c At approximately 08.00 local time (UTC $+3 \mathrm{~h}$ ) the warm air mass (originating from Muthanna/Fallujah) is rising over the colder cloud mass in the area of the detection activity indicating the occurrence of a thermal inversion; the generally brighter color is due to general warming by the rising sun. $\mathbf{d}-\mathbf{h}$ METEOSAT- 4 infrared satellite images of $2.5 \mathrm{~km}$ resolution document the same phenomenon $[54,57]$. The bright glare over the right side of $\mathbf{h}$ shows ground rewarming at $09.00 \mathrm{~h}$ local time $(\mathrm{UTC}+3 \mathrm{~h}$ ) as the region moves back into daylight. By that time, the exothermic air mass is nearing the main US and Coalition troop positions. chemical weapons detection activity was most intense on 19 January 1991 (table 1). While minimal in-theater documentation was retained, the number of triggered alarms was estimated by US Department of Defense officials at 2-3 soundings per alarm per day for each of the approximately 14,000 alarms deployed during this period [4]. 
Fig. 5. Composite weather satellite image over the Gulf War Theater of Operations on 19 January 1991. NOAA-11 composite (AVHRR visual channel 1 and infrared channels 2 and 4) image captured between 14.25 and $14.33 \mathrm{~h}$ local time (UTC $+3 \mathrm{~h}$ ) on 19 January 1991, illustrating the following phenomena: (1) a visual and thermal plume originating from the areas of the chemical warfare agent sites that had been bombed the previous night extending to the vicinity of Hafir Al Batin occupied by US and Coalition troops; (2) thermal inversion activity in the area occupied by Coalition troops, and (3) the precise Geographical Information System-determined locations of Muthanna, Fallujah and Hafir Al Batin. The image was processed with ERDAS Imagine 2011 using data archived in the NOAA Comprehensive Large Array-Data Stewardship System [34]. The yellow reference box corresponds to the one in figure 4 .

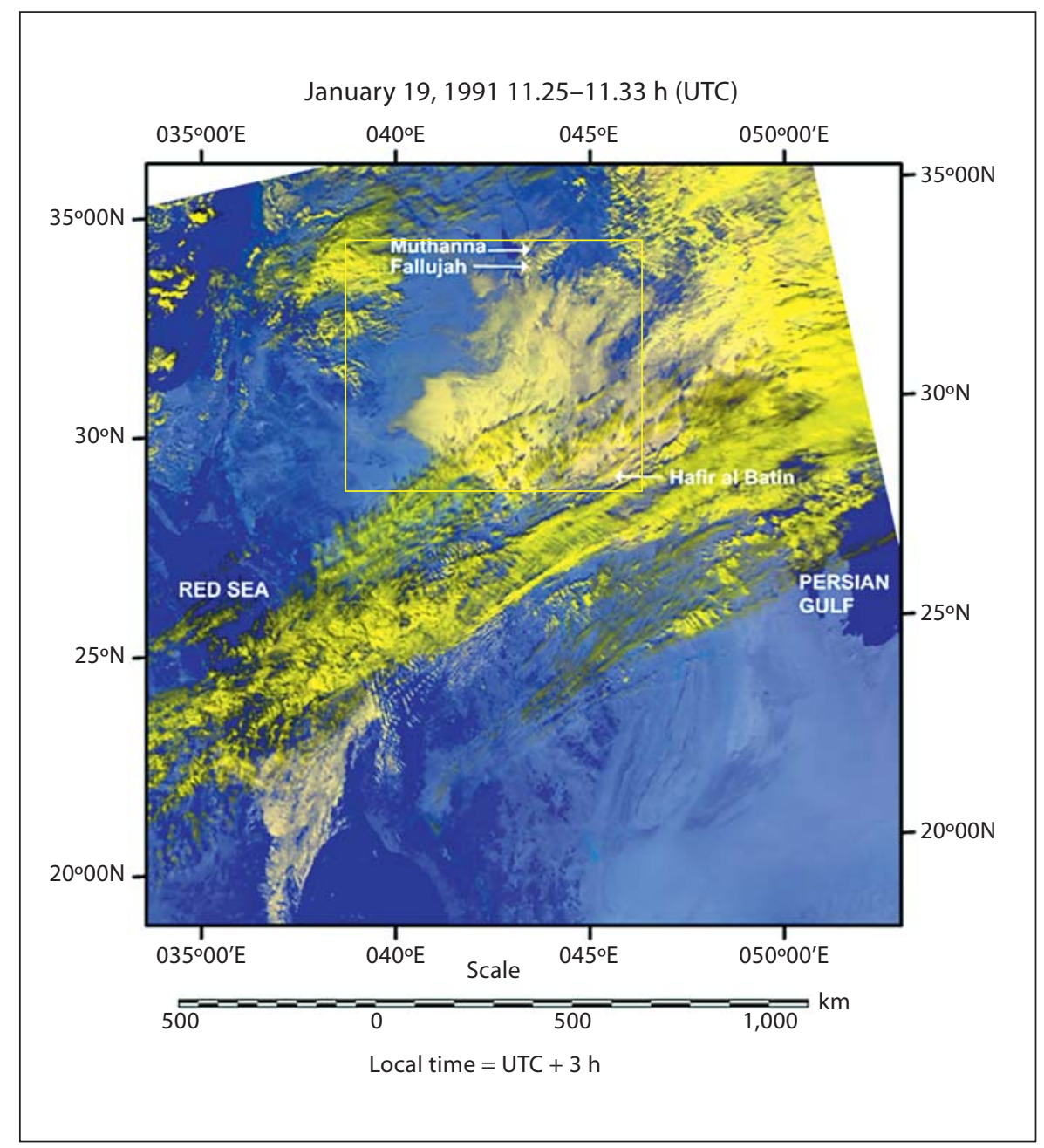

From 19 to 21 January chemical weapons experts from the US, France, Britain and Czechoslovakia, located among US and Coalition troop positions and using specialized equipment, detected both nerve agent, in several instances identified as sarin or tabun, and blister agent, identified as sulfur mustard (table 1). The best documented of these detections were made by the Czech chemical experts, who had been contracted by the Saudi government to provide chemical weapons surveillance for their troops. According to US government reporting, the Czech (and French) nerve agent and blister agent detections were made by multiple teams over a range of 20-50 $\mathrm{km}$ near the same time during a strong weather inversion on 19 January 1991 [40]. The various alarms and the detection processes utilized identification methods based on 5 different physical properties, each with its own unique spectrum of sensitivity and susceptibility to false alarms (tables 1, 2). All of these alarm and detection systems had been exposed to the same environmental conditions for months without detections until this rush of positive findings, arguing against false alarms from environmental sources. The simultaneous detection of traces of multiple chemical agents, including sarin, tabun and sulfur mustard (table 2), in the absence of evidence of a coordinated chemical attack by the Iraqis, is best explained by fallout from bombing of the large storage sites containing large quantities of the several chemical agents.

\section{Predicted Chemical Nerve Agent Exposure Levels \\ Resulting from Coalition Bombings}

Based on its performance specifications (table 2), the US M8A1 automatic nerve agent detection devices, widely deployed throughout the theater, would sound an alarm in the presence of air containing sarin at a concen- 
Table 2. Sensitivities of the chemical agent detectors/sensors deployed among Coalition forces during the 1991 Persian Gulf War

\begin{tabular}{|c|c|c|c|}
\hline Nation/system & Agents detected & Sensitivity & Identification method \\
\hline France/TDCC ${ }^{\mathrm{a}, \mathrm{d}}$ & $\begin{array}{l}\text { tabun }(\mathrm{GA}) / \text { sarin }(\mathrm{GB}) \\
\text { hydrogen cyanide }(\mathrm{AC}) \\
\text { cyanogen chloride }(\mathrm{CK})\end{array}$ & $\begin{array}{l}1 \mathrm{mg} / \mathrm{m}^{3} \\
350 \mathrm{mg} / \mathrm{m}^{3} \\
2,000 \mathrm{mg} / \mathrm{m}^{3}\end{array}$ & $\begin{array}{l}\text { chemical/biochemical detection } \\
\text { control kit }\end{array}$ \\
\hline France/AP2C/APACC ${ }^{a, d}$ & $\begin{array}{l}\text { GA/GB/soman (GD)/VX } \\
\text { sulfur mustard (HD) }\end{array}$ & $\begin{array}{l}0.01 \mathrm{mg} / \mathrm{m}^{3} \text { (vapor) } \\
0.01 \mathrm{mg} / \mathrm{m}^{2} \text { (liquid) } \\
0.1 \mathrm{mg} / \mathrm{m}^{3} \text { (vapor) } \\
0.08 \mathrm{mg} / \mathrm{m}^{2} \text { (liquid) }\end{array}$ & $\begin{array}{l}\text { flame spectrophotometry } \\
\text { (automatic detector) }\end{array}$ \\
\hline $\begin{array}{l}\text { United Kingdom/CAM } \\
\qquad(\mathrm{L} 1 \mathrm{~A} 1)^{\mathrm{c}} \\
\quad(3 \text { bar response })\end{array}$ & $\begin{array}{l}\text { GB } \\
\text { GA } \\
\text { H agents }\end{array}$ & $\begin{array}{l}0.15 \mathrm{mg} / \mathrm{m}^{3} \\
0.11 \mathrm{mg} / \mathrm{m}^{3} \\
0.16 \mathrm{mg} / \mathrm{m}^{3}\end{array}$ & ion mobility spectrometry \\
\hline United Kingdom/NAIAD ${ }^{a}$ & $\begin{array}{l}\mathrm{G} \text { agents } \\
\mathrm{V} \text { agents }\end{array}$ & $\begin{array}{l}0.05 \mathrm{mg} / \mathrm{m}^{3} \\
0.005 \mathrm{mg} / \mathrm{m}^{3}\end{array}$ & $\begin{array}{l}\text { biochemical enzyme (cholinesterase) } \\
\text { reactivity }\end{array}$ \\
\hline $\begin{array}{l}\text { Czechoslovak (CIS)/ } \\
\text { GSP-11 }^{\mathrm{d}}\end{array}$ & G/V agents & $\begin{array}{l}\text { dual sensitivity modes: } \\
-0.05 \mathrm{mg} / \mathrm{m}^{3} \\
-0.005 \mathrm{mg} / \mathrm{m}^{3}\end{array}$ & $\begin{array}{l}\text { air sampling/biochemical enzyme } \\
\text { (cholinesterase) reactivity }\end{array}$ \\
\hline $\begin{array}{l}\text { Czechoslovak (CIS)/ } \\
\text { PCHL-90 }\end{array}$ & $\begin{array}{l}\mathrm{H} \text { agents } \\
\mathrm{BZ} \\
\mathrm{GB} / \mathrm{GD} \\
\mathrm{VX}\end{array}$ & $\begin{array}{l}5 \mu \mathrm{g} \\
10 \mu \mathrm{g} \\
0.005 \mathrm{mg} / \mathrm{m}^{3} \text { (in air) } \\
0.001 \mathrm{mg} / \mathrm{l} \text { (in water) } \\
0.005 \mathrm{mg} / \mathrm{m}^{2} \text { (on surfaces) } \\
0.0005 \mathrm{mg} / \mathrm{m}^{3} \text { (in air) } \\
0.0005 \mathrm{mg} / \mathrm{l} \text { (in water) } \\
0.001 \mathrm{mg} / \mathrm{m}^{2} \text { (on surfaces) }\end{array}$ & $\begin{array}{l}\text { field portable chemical agent } \\
\text { laboratory using chemical reagents } \\
\text { and wet chemistry methods }\end{array}$ \\
\hline $\begin{array}{l}\text { United States/ } \\
\text { M8 Paper }\end{array}$ & $\begin{array}{l}\mathrm{G} / \mathrm{V} \text { agents } \\
\mathrm{H} \text { agents } \\
\text { lewisite }(\mathrm{L})\end{array}$ & $\begin{array}{l}\text { yes/no } \\
\text { yes/no } \\
\text { (responds to droplets of } \\
100 \mu \mathrm{m} \text { or larger) }\end{array}$ & chemical reactivity/color interpretation \\
\hline $\begin{array}{l}\text { United States/ } \\
\text { M9 Paper }\end{array}$ & $\begin{array}{l}\mathrm{G} / \mathrm{V} \text { agents } \\
\mathrm{H} \text { agents } \\
\mathrm{L}\end{array}$ & $\begin{array}{l}\text { yes/no } \\
\text { yes/no } \\
\text { (responds to droplets of } \\
100 \mu \mathrm{m} \text { or larger) }\end{array}$ & chemical reactivity/color interpretation \\
\hline $\begin{array}{l}\text { United States/M256/ } \\
\text { M246-A1 }\end{array}$ & $\begin{array}{l}\text { GB } \\
\text { VX } \\
\text { L } \\
\text { CK } \\
\text { AC } \\
\text { HD }\end{array}$ & $\begin{array}{l}0.005 \mathrm{mg} / \mathrm{m}^{3} \\
0.02 \mathrm{mg} / \mathrm{m}^{3} \\
8.5 \mathrm{mg} / \mathrm{m}^{3} \\
7.87 \mathrm{mg} / \mathrm{m}^{3} \\
7.88 \mathrm{mg} / \mathrm{m}^{3} \\
2.15 \mathrm{mg} / \mathrm{m}^{3}\end{array}$ & $\begin{array}{l}\text { biochemical enzyme (cholinesterase) } \\
\text { reactivity/chemical reactivity }\end{array}$ \\
\hline
\end{tabular}


Table 2 (continued)

\begin{tabular}{|c|c|c|c|}
\hline Nation/system & Agents detected & Sensitivity & Identification method \\
\hline $\begin{array}{l}\text { United States/CAM }{ }^{c} \\
\text { Type L } \\
\text { (3 bar response) }\end{array}$ & $\begin{array}{l}\text { GB } \\
\text { GA } \\
\text { H agents }\end{array}$ & $\begin{array}{l}0.15 \mathrm{mg} / \mathrm{m}^{3} \\
0.11 \mathrm{mg} / \mathrm{m}^{3} \\
0.16 \mathrm{mg} / \mathrm{m}^{3}\end{array}$ & ion mobility spectrometry \\
\hline $\begin{array}{l}\text { United States/MM1 } \\
\text { FOX NBC vehicle }\end{array}$ & $\begin{array}{l}\text { GB } \\
\text { phosgene } \\
\text { CK }\end{array}$ & $\begin{array}{l}62 \mathrm{mg} / \mathrm{m}^{3}(\mathrm{MM} 1) \\
115 \mathrm{mg} / \mathrm{m}^{3} \\
46 \mathrm{mg} / \mathrm{m}^{3} \\
\text { carries an M8A1 (M43) } \\
\text { ionization backup unit for } \\
\text { early warning; an M256A1 } \\
\text { and a CAM (see above) }\end{array}$ & $\begin{array}{l}\text { quadrupole gas chromatography/ } \\
\text { mass spectrometry (GC/MS) } \\
60 \text { preprogrammed agent spectra } \\
\text { full GC-MS }\end{array}$ \\
\hline
\end{tabular}

Detection/sensing specifications obtained from the following sources: ${ }^{\text {a }}$ Janes NBC Protection Equipment [49]. ${ }^{\mathrm{b}}$ National Institute of Justice (values converted from $\mathrm{ppm}$ to $\mathrm{mg} / \mathrm{m}^{3}$ ) [50]. ${ }^{\mathrm{c}}$ Longworth and Ong [51]. ${ }^{\mathrm{d}}$ Worldwide Chemical Detection Equipment Handbook [52]. ${ }^{\text {e }}$ Report of the Defense Science Board (DSB) Task Force on Persian Gulf War Health Effects, table 18 [10].
Identification of detection equipment obtained from the following sources: Janes NBC Protection Equipment [49]. Case narrative: Czech and French reports of possible chemical agent detections [6]; Czech Chemical Warfare Report [53]. tration of $0.11 \mathrm{mg} / \mathrm{m}^{3}$ or higher. Since M8A1 alarms were frequently sounding over a wide area for several days around 19 January 1991 [4] while sarin was being reliably confirmed by more sensitive testing by the Czechs and French using different technologies (table 1), it is reasonable to conclude that sarin exposures to concentrations at or above $0.11 \mathrm{mg} / \mathrm{m}^{3}$ were widespread and repetitive.

\section{Potential Health Consequences of Repetitive \\ Low-Level Sarin Exposures}

According to the evidence-based Acute Exposure Guideline Levels (AEGL) for sarin, developed by the National Research Council for the US Environmental Protection Agency (EPA) [41], airborne exposure to a sarin concentration of $0.11 \mathrm{mg} / \mathrm{m}^{3}$ (the lower detection limit of the US M8A1 nerve agent alarm unit) for at least $10 \mathrm{~min}$ would exceed the AEGL-2 threshold (fig. 7). With exposure above this threshold 'it is predicted that the general population, including susceptible individuals, could experience irreversible or other serious, long-lasting adverse health effects or an impaired ability to escape,' and some degree of miosis (pupillary constriction) and dyspnea (breathing difficulty) would be expected [41].

Miosis and dyspnea were not commonly reported among the exposed troops, but other symptoms compatible with mild cholinergic stimulation, such as stomach cramps, urge to urinate or defecate, and diarrhea, however, were common during the conflict period [4]. These symptoms might have indicated early sarin toxicity, but they were difficult to distinguish from the cholinergic side effects of the pyridostigmine bromide anti-nerve agent medication many personnel were ordered to take when nerve agent exposures appeared imminent or from infectious gastroenteritis.

That most soldiers had chemical warfare agent protective suits (Mission-Oriented Protective Posture, or MOPP gear) and were trained to don them immediately upon hearing nerve agent alarms undoubtedly minimized the duration of exposure to potentially AEGL-2 levels of ambient sarin when nerve agent alarms sounded (fig. 7). This may explain the absence of miosis and dyspnea - donning protective gear when ambient concentrations triggered alarms may have kept the exposure of any single ambient concentration spike to just at or under the AEGL-2 threshold. But no matter how quickly protective MOPP gear was donned, some cutaneous and respiratory absorption occurred.

In between the alarms, however, it is unlikely that ambient nerve agent concentrations immediately dropped to nothing. More likely, the periodic sounding of nerve agent alarms indicated sustained exposure to fluctuating levels generally below the AEGL-2 threshold above which miosis and dyspnea would occur - the duration of these sustained, low-level exposures varying geographically. The number of nerve agent exposures, indicated by the number of times alarms sounded, is known to have varied widely among deployed personnel from none or only 1 per soldier to dozens over the full conflict period. 


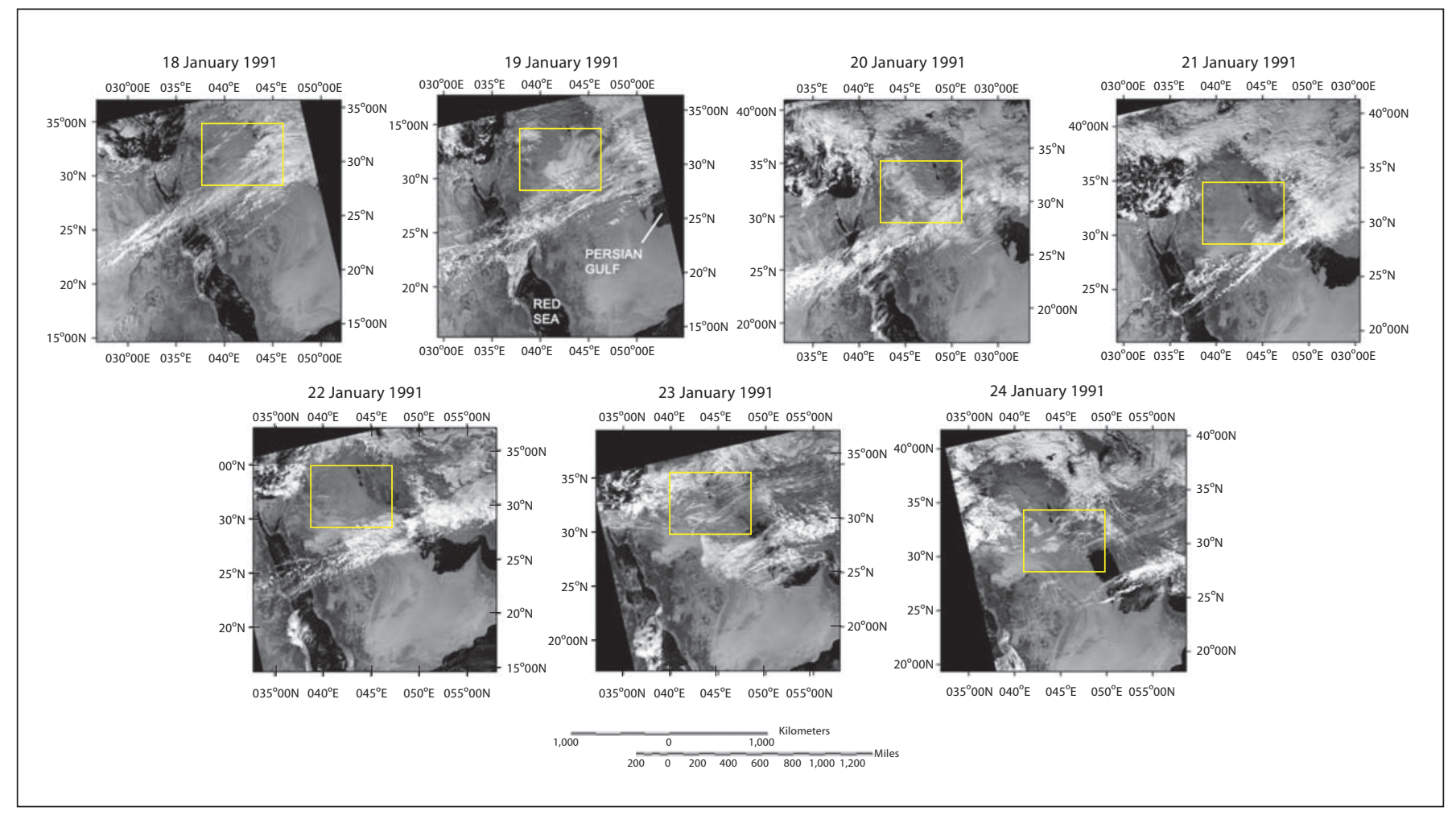

Fig. 6. Daily near-infrared images of the Kuwaiti Theater of Operations by the NOAA-11 AVHRR 1B meteorological satellite spanning 18-24 January 1991. The 7 daily images document a near-stationary weather front persisting over US troop positions in Saudi Arabia. The 19-January image shows a large cloud, not present the day before, arising east of Lakes Tharthar and Hab- baniyah (fig. 1 for reference), spreading southeast, south and southwest into the frontal cloud mass, and persisting through the 24-January image. The images were processed with ERDAS Imagine 2011 software using data archived in the NOAA Comprehensive Large Array-Data Stewardship System [34]. The yellow reference box corresponds to the one in figure 4 .
The potential for this type of sustained, low-level exposure to affect health turns on the research finding that the chronic nervous system effects of sarin, even at very low doses, are cumulative over time. Toxicologic animal studies have found that repetitive exposure to low, subsymptomatic doses of sarin (generally $<0.3$ LD50 or LCt50) produce long-lasting EEG changes in nonhuman primates [42], delayed alteration of brain acetylcholine receptors in rats [43], chronic behavior changes in rats $[44,45]$, and autonomic disturbances in mice [46]. Van Helden et al. [47] in a dose-finding pilot study further suggested that the lowest level of sarin exposure that permanently alters the EEG of nonhuman primates (0.1-0.2 $\mathrm{mg} \mathrm{min} \mathrm{m}^{-3}$ corresponding to a sarin concentration of $0.0073-0.014 \mathrm{mg} \mathrm{m}^{-3}$ ) may be at least an order of magnitude lower than the level that causes miosis or is detected by the M8A1 nerve agent alarm.

\section{Discussion}

The following chain of findings of this study provide a plausible explanation, supported by empirical evidence, for how fallout from the bombings of the Muthanna/Fallujah chemical warfare production and storage facilities near Baghdad, the night of 18-19 January 1991 early in the air campaign, could have traveled overnight to distant US and Coalition troop positions in northern Saudi Arabia, setting off nerve agent alarms without causing mass casualties in between. (i) Explosions of large bombs in chemical weapons storage facilities on a cold night would be expected to propel a debris cloud containing sarin nerve agent through the calm atmospheric NBL to the higher altitude RL, preventing dispersion at ground level. (ii) Sarin, which evaporates at about the same rate as water, does not burn [28]. Much of the sarin in the debris cloud would have remained active in vapor form during the following day when the initial detections were made. 


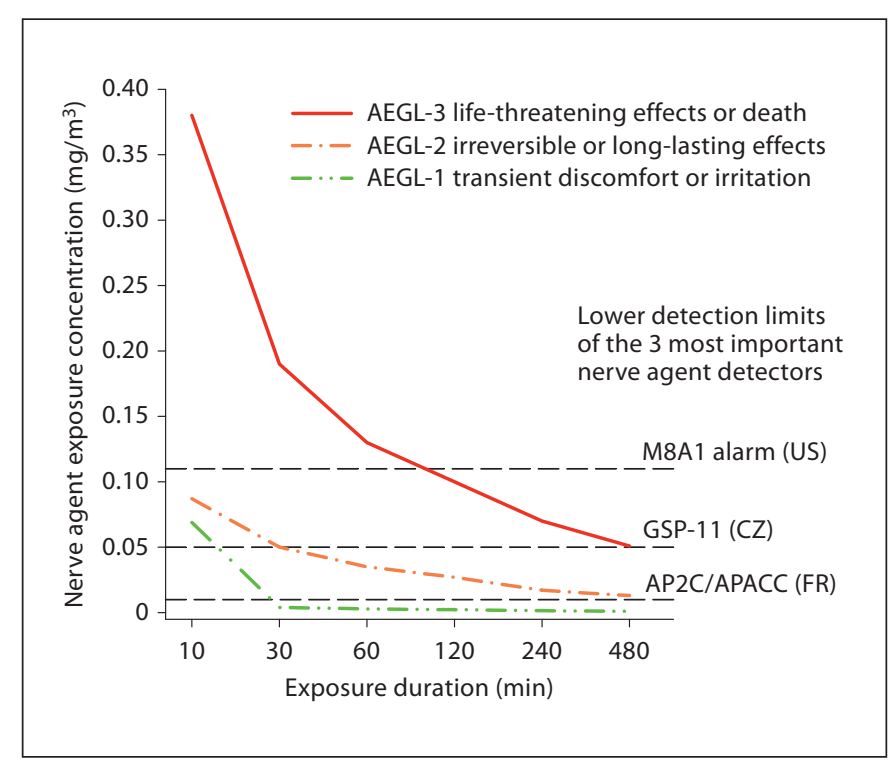

Fig. 7. Prediction of irreversible or long-lasting health effects in soldiers located where M8A1 nerve agent detection alarms sounded, based on the device's lower detection limit and known health effects at various US EPA AEGL. Based on the data in table 2, any M8A1 (US) alarm sounding suggests exposures above the AEGL2 threshold. This analysis suggests that medically important exposures during the air campaign can be bounded by the M8A1 detection threshold $\left(0.11 \mathrm{mg} / \mathrm{m}^{3}\right)$ and the AEGL-3 minimum, since no deaths were attributed to acute nerve agent poisoning. During the early air campaign, ambient nerve agent was detected by three fundamentally different technologies: ionization (US), biochemical enzyme reactivity (Czech) and flame spectrophotometry (French) (table 2), each having its own levels of sensitivity, specificity and susceptibility to false alarms. The greater sensitivity of the Czech GSP-11 $\left(0.05 \mathrm{mg} / \mathrm{m}^{3}\right)$ and the French AP2C/ APACC $\left(0.01 \mathrm{mg} / \mathrm{m}^{3}\right)$ detection devices explains the frequent repeated Czech and French detections. The AEGL levels define the airborne concentration-time thresholds (expressed as $\mathrm{mg} / \mathrm{m}^{3}$ ) of a substance as the level above which the general population, including susceptible individuals, could be expected to experience the following adverse effects: AEGL-1 = notable discomfort, irritation, or certain asymptomatic nonsensory effects that are not disabling and are transient and reversible upon cessation of exposure; AEGL-2 = irreversible or other serious, long-lasting adverse health effects or an impaired ability to escape; AEGL-3 = lifethreatening health effects or death [41].

(iii) Weather charts indicate that the higher level winds above the NBL were blowing from the northwest, just the right direction to transit the debris cloud toward US and Coalition troop positions to the southeast. (iv) Weather satellite imagery on the night of 18-19 January 1991 shows a mass of warm air originating over the Muthanna/Fallujah chemical weapons research, production and storage facilities and transiting rapidly overnight to the south and southeast. The warm air mass is further seen arriving in northern Saudi Arabia in the early morning hours just as the rising sun and associated thermal activity mixed the NBL and the RL of the preceding night. This mixing and the subsequently observed inversion activity of 19 January would have brought the debris cloud back down to the surface, resulting in the chemical warfare agent alarms and detections. (v) A relatively stationary weather front over Saudi Arabia holding the fallout in place and further transit from continued bombing in Iraq explain repetitive or sustained low-level exposures over several days. During this time more chemical alarms sounded both due to daytime mixing of atmospheric layers and following nocturnal turbulence-causing events such as incoming artillery and SCUD missiles and sonic booms from jet aircraft.

\section{Parallel with the Chernobyl Nuclear Accident}

The plausibility of the long-distance transit phenomenon suggested in this paper is supported by the close parallel with the initial atmospheric transport of radioactive fallout from the explosion and fire at the Chernobyl nuclear reactor in 1986, which was quickly recognized and extensively documented in real time [48]. The violent reactor explosions, occurring at 1.23 a.m. local time, propelled the radioactive fallout cloud far above the calm NBL. Rapid horizontal transit by advection currents carried the fallout over $1,000 \mathrm{~km}$ overnight. During longdistance transit the fallout remained largely in a stable air mass with limited dispersion and dilution, preventing significant ground contamination. The fallout cloud was eventually stalled by a thermal inversion over southern Sweden and there came back to ground through mixing of atmospheric layers by daytime heating. The fallout exposure was not initially concentrated in areas immediately around the Chernobyl emission site but instead transited long distances with little ground exposure before reaching Sweden. Nuclear monitoring sites and surveillance aircraft were already in place to detect the pattern of radioactive fallout from Chernobyl, whereas in the Gulf War, widespread nerve agent alarms and sophisticated nerve agent detection stations, deployed by several countries for defensive surveillance, detected the chemical nerve agent fallout. The high-altitude Chernobyl fallout cloud was documented by aircraft already in place for routine monitoring of atmospheric radiation levels; whereas, in the Gulf War transit of the hot air mass from the bombing explosions was documented from heat signatures captured on weather satellite imagery. Thus, 
the phenomenon of long-distance transit of the fallout cloud causing nerve agent exposure hundreds of kilometers away without casualties in between has close precedent in the initial phase of the Chernobyl accident.

\section{Strengths and Weaknesses of This Study}

One of the main strengths of this study is the introduction of the concepts of boundary layer meteorology [26] to explain how the long-distance transit of chemical warfare agent could have occurred without intervening casualties. In fact, given the large size of the warm air mass that was documented by the photographic and infrared weather satellite imagery, the absence of proximate casualties could only be explained by the NBL penetration that partitioned the fallout away from the human populations nearby at ground level. This explanation thus provides answers to the question that, while unanswered, caused intelligence experts during and after the war to discount the possibility of long-distance transit of sarin early in the air campaign and to leave the many nerve agent alarms and detections unexplained.

A weakness of the study is the lack of availability of ground station weather data, such as wind speeds at various locations and at different atmospheric levels, since in 1991 Iraq did not report weather measurements to the World Meteorological Organization. Consequently, there is insufficient information to produce precise mathematical modeling of the sarin concentrations to which troops may have been exposed. Predicting precise exposure levels from computer modeling, however, is less important in this case because exposure estimates at least as accurate can be inferred from the large number of nerve agent alarms and expert detections early in the air campaign and the known sensitivity levels of these devices. Together these data establish that large numbers of US and Coalition military personnel were exposed to levels of sarin rated by the US EPA as AEGL-2, which is high enough to cause irreversible or other serious, long-lasting adverse health effects' [41].

\section{Conclusions}

The review of intelligence data presented in this article provides an explanation, as well as direct confirmation, of how repetitive exposure to low-level sarin nerve agent resulted from fallout that transited long-distance from US and Coalition bombing of the Iraqi chemical weapons research, production and storage facilities during the air campaign of the 1991 Persian Gulf War. The main reason this explanation was not accepted during or soon after the war was the reliance on ATD modeling of exposure, which assumed transit at ground level, which would have produced casualties near the bombed sites. The introduction of observations based on boundary layer meteorology [26] as well as corroboratory evidence from existing weather charts and meteorological weather satellite imagery, which closely parallel the well-documented longdistance transit of radioactive fallout from the Chernobyl accident [48], removes the objection to this explanation. Where possible, the data from prior epidemiologic studies should be reassessed with multivariable analysis of a case definition comparing the dose-related effects of veterans' reports of hearing nerve agent alarms and location in the computer-modeled Khamisiyah plume to see if more consistent associations would result. The companion paper [20] reports the results of a large population-based epidemiologic study designed specifically to make this comparison.

\section{Funding}

No funding support was received for this work.

\section{Disclosure Statement}

Jim Tuite is a an international security and risk management consultant, who was employed as a national security advisor to the chairman of the first US Senate committee to investigate possible causes of Gulf War illness in the early 1990s. From 2002 to 2007, he served on the Expert Advisory Panel to the Department of Veterans' Affairs Research Advisory Committee on Gulf War Veterans' Illnesses. Subsequently he was employed as a national security advisor to the President pro tempore of the US Senate and as an expert consultant on Gulf War illnesses and emerging security threats to the US Government Accountability Office and in Gulf War-related litigation. While he compiled much of the intelligence information in the course of his prior official employment, he received no compensation for preparing this paper.

Dr. Robert Haley, an internist and epidemiologist employed full time as a faculty member of the University of Texas Southwestern Medical Center, has directed research on Gulf War illnesses since 1994, published extensively in scientific journals, served on the Department of Veterans' Affairs Research Advisory Committee on Gulf War Veterans' Illnesses, and received honoraria and fees for lecturing and consulting on this subject. He has directed epidemiologic and clinical research on Gulf War illness supported by the Perot Foundation and the US Departments of Defense and Veterans Affairs. His contributions to this paper were performed as part of his regular university faculty activities without external funding support.

The content of this paper does not necessarily reflect the position or the policy of the Federal government, and no official endorsement should be inferred. 


\section{References}

1 Department of Defense: Final Report to Congress: Conduct of the Persian Gulf War. 1992. http://www ndu edu/library/epubs/ cpgw pdf.

2 General Accounting Office: Operation Desert Storm: Evaluation of the Air Campaign, GAO-NSIAD 97-134. 1997. http://www gao gov/archive/1997/ns97134 pdf.

3 Defense Intelligence Agency: Battlefield Damage Assessment (BDA) 81-91. 1991. http://www gulflink osd mil/al_muth/al muth_refs/n58en047/961031_950925_081b da $91 \mathrm{p}$ htm.

4 Committee on Banking, Housing, and Urban Affairs: United States Dual-Use Imports to Iraq and their Impact on the Health of Persian Gulf War Veterans. 1994. http://www gulfweb org/bigdoc/report/rieglel html.

5 Office of Inspector General: Exhibit 3. CENTCOM NBC Desk Log 19-28 January. Report of Investigation Concerning the Missing US Central Command Nuclear, Biological and Chemical Desk Logs. 10-20-1997. http://www gulflink osd mil/dodig/exhibit3 htm

6 Office of the Special Assistant for Gulf War Illnesses: Case narrative: $\mathrm{Czech}$ and French reports of possible chemical agent detections. 1998. http://www gulflink osd mil/ czech_french/.

7 General Accounting Office: Gulf War illnesses: DoD's Conclusions about US Troops' Exposure Cannot Be Adequately Supported, Report to the Congressional Requesters (GAO-04-159 Gulf War Illnesses). 2004. http://www gao gov/new items/d04159 pdf.

$>8$ Gray GC, Smith TC, Knoke JD, Heller JM: The postwar hospitalization experience of Gulf War Veterans possibly exposed to chemical munitions destruction at Khamisiyah, Iraq. Am J Epidemiol 1999;150:532540.

9 Central Intelligence Agency: CIA Report on Intelligence Related to Gulf War Illnesses. 1996. http://www fas org/irp/gulf/cia/ 102496_w htm.

10 Lederberg J: Report of the Defense Science Board (DSB) Task Force on Persian Gulf War Health Effects. 1994. http://www gulflink osd $\mathrm{mil} / \mathrm{dsbrpt} /$.

11 Lashof JC, Landrigan PJ, Hamburg DA, Caplan A, Cross TP, Johnson JA, Knox M, Larson EL, Rios R, Taylor AK: Presidential Advisory Committee on Gulf War Veterans' Illnesses: Final Report. Washington, US Government Printing Office, 1996.

12 Fulco CE, Liverman CT, Sox HC (eds): Gulf War and Health. Washington, National Academy Press, 2000, vol 1: Depleted Uranium, Pyridostigmine Bromide, Sarin, and Vaccines.

13 Winkenwerder W Jr: US demolition operations at Khamisiyah. Final report. 2002. http://www gulflink osd mil/khamisiyah iii/.
14 Office of the Special Assistant for Gulf War Illnesses: Case Narrative: US Demolition Operations at the Khamisiyah ammunition storage point. 4-14-1997. http://www gulflink osd mil/khamisiyah_ii/index html.

15 Office of the Special Assistant for Gulf War Illnesses: Case Narrative: US Demolition Operations at Khamisiyah. 12-72000. http:// www gulflink osd mil/khamisiyah_ii/index html.

16 Yokoyama K, Araki S, Murata K, Nishikitani $\mathrm{M}$, Okumura $\mathrm{T}$, Ishimatsu S, Takasu $\mathrm{N}$ : Chronic neurobehavioral and central and autonomic nervous system effects of Tokyo subway sarin poisoning. J Physiol Paris 1998 ; 92:317-323.

17 Yamasue H, Abe O, Kasai K, Suga M, Iwanami A, Yamada H, Tochigi M, Ohtani T, Rogers MA, Sasaki T, Aoki S, Kato T, Kato N: Human brain structural change related to acute single exposure to sarin. Ann Neurol 2007;61:37-46.

18 Hyams KC, Brown M, White DS: Resolving disputes about toxicological risks during military conflict: the US Gulf War experience. Toxicol Rev 2005;24:167-180.

19 Brown M: Toxicological assessments of Gulf War veterans. Phil Trans R Soc B 2006; 361:649-679.

20 Haley RW, Tuite JJ: Epidemiologic evidence of health effects from long-distance transit of chemical weapons fallout from bombing early in the 1991 Persian Gulf war. Neuroepidemiology 2013;40:178-189.

21 United Nations Special Commission on Iraq (UNSCOM): Letter dated 25 January 1999 from the Executive Chairman of the Special Commission established by the SecretaryGeneral pursuant to paragraph 9 (b) (i) of Security Council resolution 687 (1991) addressed to the President of the Security Council. 1999. http://www fas org/news/un/ iraq/s/990125/index html.

22 Washington Post: UNSCOM Tracks Terror Weapons: Washington Post Map. 1998. http://www washingtonpost com/wp-srv/ inatl/longterm/iraq/maps/iraqgeneral/front htm.

23 Institute of Medicine: Gulf War and Health. Vol 1: Depleted Uranium, Pyridostigmine Bromide, Sarin, Vaccines; vol 2: Insecticides and Solvents; Updated Literature Review on Sarin; vol 3: Fuels, Combustion Products, and Propellants. 2000. http://www iom edu/ report asp?id=24236.

24 Church HW: Cloud Rise from High-Explosives Detonations, Tech Rep No SCRR-68-903. 1969. http://www osti gov/ bridge/product biblio jsp?osti_id $=4798257$.

25 Price DE, Halstead J, Hickman R, Hildum B, Odell B: Chemical Facility Release Analysis Methodology for LLNL. Tech Rep No UCRLJC-129397. Livermore, Lawrence Livermore National Laboratory, 1998.
26 Stull RB: Atmospheric Sciences Library: An Introduction to Boundary Layer Meteorology. Norwell, Kluwer, 1988.

27 National Climatic Data Center: Northern Hemisphere Surface Charts and $850 \mathrm{mb}$ Pressure Charts, January-February-March 1991 (available on microfilm from NCDC) - Station 17280 (Diyarbakir, Turkey) $2^{\circ} \mathrm{C}$; station 40712 (Orumieh, Iran $\left(37^{\circ} 32^{\prime} \mathrm{N} 045^{\circ} 05^{\prime} \mathrm{E}\right)$ ) $-4^{\circ} \mathrm{C}$; station 40754 (Tehran-Mehrab, Iran $\left(35^{\circ} 41^{\prime} \mathrm{N} 051^{\circ} 21^{\prime} \mathrm{E}\right)$ ) $3^{\circ} \mathrm{C}$; and station 40500 (Unidentified) $2^{\circ} \mathrm{C}$. Station 40611 (Salahaddin, Iraq $\left(36^{\circ} 37^{\prime} \mathrm{N} 044^{\circ} 13^{\prime} \mathrm{E}\right)$ ) no report. Asheville, US Department of Commerce, National Oceanic and Atmospheric Administration, Environmental Data and Information Service, National Climatic Data Center, 1991.

28 Compton JAF: Chemical and Biological Agents: Chemical and Toxicological Properties. Caldwell, Telford Press, 1987.

29 National Oceanic and Atmospheric Administration: Joint Action Group for Atmospheric Transport and Diffusion Modeling (Research and Development Plan): Modeling and Measurement Needs. 2004. http://www ofcm gov/r23/r23-2004/pdf/fcm-r23-2004 pdf.

30 Lundquist JK, Mirocha JD: Interaction of nocturnal low-level jets with urban geometries as seen in joint urban 2003 data. J Appl Meteorol Climatol 2008;47:44-58.

>31 Liu M, Westphal DL, Holt TR, Xu Q: Lowlevel jet over complex terrain in Southern Iran. Month Weath Rev 2000;128:13091327.

32 US Air Force Environmental Technical Applications Center: US Air Force. Gulf War Weather, Tech Rep No USAFETAC/TN-92003. Washington, National Technical Information Service, 1991.

33 National Climatic Data Center: Northern Hemisphere Surface Charts and $850 \mathrm{mb}$ Pressure Charts, January-February-March 1991. Washington, US Department of Commerce, National Oceanic and Atmospheric Administration, Environmental Data and Information Service, National Climatic Data Center, 1991.

34 National Oceanic and Atmospheric Administration: Comprehensive Large Array-data Stewardship System (CLASS): AVHRR. 2012. http://www class ngdc noaa gov/data available/avhrr/index htm.

35 Weinstein LM, Kathryn S, Vieira Gerald J, Edward AH Jr, Bowers AH: Visualization and Image Processing of Aircraft Shock Wave Structures, Technical Report: NASA97-1psfvip-Imw. Houston, NASA Langley Technical Report Server, 1997.

36 Jones T: Chemical Fallout Reported in Iraq; Official Goes to Saudi Arabia (February 3, 1991). Washington, Associated Press, 1991. 
37 Xinhua General News Service: Chemical fallout detected in Iraq (February 4, 1991). Beijing, PRC, Xinhua General News Service, 1991.

38 Department of Defense: Detection of Chemical Agents by Czechoslovak Unit During Desert Storm, Part III (U), IIR 6824000894. Washington, US Department of Defense, 1993.

39 Department of Defense: CENTCOM CCJ3$\mathrm{X} \log$ (partially declassified). Washington, US Department of Defense, 1995.

40 Defense Intelligence Agency: Detection of Chemical Warfare Agents by Czechoslovak Unit during Desert Storm, Part III (U), IIR 6 2840008 94. Washington, Defense Intelligence Agency, 1993.

41 National Research Council: Acute exposure guideline levels for selected airborne chemicals, vol 3. 2012. http://www epa gov/oppt/ aegl/pubs/tsd21 pdf.

42 Burchfiel JL, Duffy FH, Van SM: Persistent effects of sarin and dieldrin upon the primate electroencephalogram. Toxicol Appl Pharmacol 1976;35:365-379.

-43 Henderson RF, Barr EB, Blackwell WB, Clark CR, Conn CA, Kalra R, March TH, Sopori ML, Tesfaigzi Y, Menache MG, Mash DC: Response of rats to low levels of sarin. Toxicol Appl Pharmacol 2002;184:67-76.

-44 Kassa J, Pecka M, Tichy M, Bajgar J, Koupilova M, Herink J, Krocova Z: Toxic effects of sarin in rats at three months following single or repeated low-level inhalation exposure. Pharmacol Toxicol 2001;88:209-212.

45 Scremin OU, Shih TM, Huynh L, Roch M, Booth R, Jenden DJ: Delayed neurologic and behavioral effects of subtoxic doses of cholinesterase inhibitors. J Pharmacol Exp Ther 2003;304:1111-1119.
46 Morris M, Key MP, Farah V: Sarin produces delayed cardiac and central autonomic changes. Exp Neurol 2007;203:110-115.

47 van Helden HP, Trap HC, Oostdijk JP, Kuijpers WC, Langenberg JP, Benschop HP: Long-term, low-level exposure of guinea pigs and marmosets to sarin vapor in air: lowest observable effect level. Toxicol Appl Pharmacol 2003; 189:170-179.

48 Persson C, Rodhe H, de Geer L-E: The Chernobyl accident-a meteorological analysis of how radionuclides reached and were deposited in Sweden. Ambio 1987;16:20-31.

49 Gander TJ: Jane's NBC Protection Equipment 1991-1992, 1995-1996, ed 8. Englewood, Janes Information Group, 1995.

50 National Institute of Justice, US Department of Justice: Guide for the Selection of Chemical Agent and Toxic Industrial Material Detection Equipment for Emergency First Responders, NIJ Guide 100-00, vol II. 2000. https://www ncjrs gov/pdffiles1/nij/184450 pdf.

51 Longworth TL, Ong KY: Domestic Preparedness Program: Testing of the CAM Chemical Agent Monitor (Type L) against Chemical Warfare. 2001. https://www ecbc army mil/downloads/reports/ECBC_cam_ typel pdf.

52 Brletich NR: Worldwide Chemical Detection Equipment Handbook. Aberdeen Proving Ground, Chemical and Biological Defense Information Analysis Center (CBIAC), 1995.

53 US Army Foreign Science and Technology Center and the Defense Intelligence Agency: Czech Chemical Warfare Report: Intelligence Assessment of Chemical and Biological Warfare in the Gulf: Prepared for the Defense Science Board investigating the Desert Storm Syndrome. 2002. http://www gulflink osd mil/czech_french/czfr_refs/n08en038/ 950925_0401pgf_93 html.
54 ERDAS: ERDAS IMAGINE Suite (geospatial and map visualization software). Version 8.2. Atlanta, ERDAS, 1996.

55 National Climatic Data Center: NOAA-10, NOAA-11 AVHRR Level 1B image data. Washington, US Department of Commerce, National Oceanic and Atmospheric Administration, National Climatic Data Center, 1991.

56 National Climatic Data Center: NOAA-10, 11 AVHRR Level 1B (IR Channel 4) data files， NSS.GHRR.NG.D91018.S1506.E1636. B2252627.GC, NOAA-11 AVHRR Level 1B (IR Channel 4) data file, NSS.LHRR. NH.D91019.S0008.E0018.B1194141.GC, NOAA-10 AVHRR Level 1B (IR Channel 4) data file, NSS.GHRR.NG.D91019.S0405. E0552.B2253435.GC. Washington, US Department of Commerce, National Oceanic and Atmospheric Administration, National Climatic Data Center, 1991.

57 European Organisation for the Exploitation of Meteorological Satellites (EUMETSAT): METEOSAT-4 (IR Channel) data file, OpenMTP_1991-01-18_37_412345_1_1_1.IR, METEOSAT-4 (IR Channel) data file, OpenMTP_1991-01-18_43_412345_1_1_1.IR, METEOSAT-4 (IR Channel) data file, OpenMTP_1991-01-19_01_412345_1_1_1.IR, METEOSAT-4 (IR Channel) data file, OpenMTP_1991-01-19_07_412345_1_1_1.IR, METEOSAT-4 (IR Channel) data file, OpenMTP_1991-01-19_13_412345_1_1_1.IR. Darmstadt, Germany, European Organisation for the Exploitation of Meteorological Satellites (EUMETSAT), 1991. 